CLINICAL STUDY

\title{
Usefulness of the desmopressin test in the postoperative evaluation of patients with Cushing's disease
}

\author{
Paolo Colombo ${ }^{1}$, Chiara Dall'Asta, Laura Barbetta, Tiziana Re, Elena Passini, Giovanni Faglia \\ and Bruno Ambrosi \\ Istituto di Scienze Endocrine, Università di Milano, Ospedale Maggiore IRCCS, Milano, Italia and ${ }^{1}$ Istituto Clinico Humanitas, Rozzano, Italia \\ (Correspondence should be addressed to B Ambrosi, Institute of Endocrine Sciences, Ospedale Maggiore, IRCCS, via F. Sforza, 35-20122 Milan, Italy; \\ Email: Bruno.Ambrosi@unimi.it)
}

\begin{abstract}
Objective: To evaluate the plasma ACTH and serum cortisol responses to desmopressin in patients with Cushing's disease either before or after pituitary adenomectomy during long-term follow-up, and to compare the results with those obtained after corticotrophin-releasing hormone (CRH) testing. Design: Plasma ACTH and serum cortisol concentrations were evaluated after the administration of desmopressin $(10 \mu \mathrm{g}$ i.v. $)$ or CRH $(1 \mu \mathrm{g} / \mathrm{kg}$ i.v. $)$ in 34 patients with Cushing's disease. Twenty-four patients with active Cushing's disease were evaluated both before and after transsphenoidal pituitary surgery (TSS); these patients were followed up for 1-36 months. Ten patients were studied only after a long-term period (1-19 years, median 4 years) after TSS (six patients), TSS plus external pituitary irradiation (three patients) and TSS plus radiosurgery (one patient).

Results: In 24 patients with active Cushing's disease a significant ACTH/cortisol response $(P<0.001)$ was induced by either desmopressin (ACTH from a baseline of $15.3 \pm 2.7 \mathrm{pmol} / \mathrm{l}$ to a peak of $40.9 \pm 7.3 \mathrm{pmol} / \mathrm{l}$; cortisol from $673 \pm 59 \mathrm{nmol} / \mathrm{l}$ to $1171 \pm 90 \mathrm{nmol} / \mathrm{l}$ ) or CRH (ACTH from a basal of $14.2 \pm 2.5 \mathrm{pmol} / \mathrm{l}$ to a peak of $47.2 \pm 7.7 \mathrm{pmol} / \mathrm{l}$; cortisol from $672 \pm 50 \mathrm{nmol} / \mathrm{l}$ to $1192 \pm$ $80 \mathrm{nmol} / \mathrm{l})$. In all patients a positive cortisol response to desmopressin was found. After pituitary adenomectomy the 14 'cured' patients were followed up for 1-36 months; desmopressin administration never induced ACTH or cortisol responsiveness in any patient. In contrast, a progressive recovery of ACTH and cortisol responses after CRH was observed at different intervals of time in all patients but one.

Five patients, in whom the cortisol concentration only normalized after surgery, showed a persistent responsiveness to desmopressin, and two of them relapsed 12 and 24 months later. In five patients who were not cured, the hormonal responsiveness to either CRH or desmopressin was similar before and after operation. Of 10 patients studied only after long-term follow-up, six were cured and a normal response to $\mathrm{CRH}$ was present, whereas no changes in ACTH/cortisol concentrations were induced by desmopressin. The other four unsuccessfully operated patients underwent pituitary irradiation and showed different and equivocal hormonal responses to desmopressin and to CRH.

Conclusions: During the postoperative follow-up of patients with Cushing's disease, the maintenance or the disappearance of the hormonal response may be related to the persistence or the complete removal of adenomatous corticotrophs, respectively. It is suggested that desmopressin test should be performed in the preoperative evaluation and follow-up of patients with ACTH-dependent Cushing's syndrome.
\end{abstract}

European Journal of Endocrinology $143227-234$

\section{Introduction}

Corticotrophin-releasing hormone $(\mathrm{CRH})$ has been used extensively for the differential diagnosis of Cushing's syndrome, causing significant ACTH/cortisol responses in most patients with Cushing's disease, but rarely in other forms of hypercortisolism (1).

Similar results have been obtained also with the synthetic analogue of vasopressin, lysine-vasopressin
(LVP) (2), through the action on V3 receptors recently cloned in the pituitary $(3-5)$.

More recently, another synthetic vasopressin analogue, desmopressin, with more selective affinity for the renal V2 receptor but also able to interact with the V3 receptor, has been shown to induce significant increases in ACTH/cortisol in the majority of patients with Cushing's disease, but not in normal individuals (68 ). This latter finding might be of interest in clinical 
Table 1 Some clinical characteristics of 34 patients with Cushing's disease, early postoperative results, and final outcome after follow-up.

\begin{tabular}{|c|c|c|c|c|c|c|c|}
\hline Patient No. & $\begin{array}{c}\text { Age } \\
\text { (years) }\end{array}$ & Sex & Treatment & $\begin{array}{l}\text { Cortisol conen } \\
\text { after TSS } \uparrow \\
(\text { nmol/l) }\end{array}$ & $\begin{array}{c}\text { Subsequent } \\
\text { treatment }\end{array}$ & $\begin{array}{c}\text { Final } \\
\text { outcome }\end{array}$ & $\begin{array}{l}\text { Follow-up } \\
\text { (months) }\end{array}$ \\
\hline 1 & 26 & $\mathrm{~F}$ & TSS & 27 & - & Cure & 12,24 \\
\hline 2 & 28 & $\mathrm{~F}$ & TSS + TSS & 49 & - & Cure & 12,36 \\
\hline 3 & 68 & $\mathrm{~F}$ & TSS & 22 & - & Cure & $1,6,12,24$ \\
\hline 4 & 33 & $\mathrm{~F}$ & TSS & 27 & - & Cure & $1,6,12,18,24,36$ \\
\hline 5 & 13 & $\mathrm{~F}$ & TSS & $<10$ & - & Cure & 1 \\
\hline 6 & 38 & $\mathrm{~F}$ & TSS & 118 & - & Cure & $1,6,12,18,24,36$ \\
\hline 7 & 34 & $\mathrm{~F}$ & TSS & 37 & - & Cure & $1,6,12,18,24$ \\
\hline 8 & 31 & $\mathrm{~F}$ & TSS & 100 & - & Cure & $1,6,12,18,24$ \\
\hline 9 & 70 & $\mathrm{~F}$ & TSS & 107 & - & Cure & $1,6,12,24$ \\
\hline 10 & 15 & M & TSS & $<10$ & - & Cure & $1,6,12,18,24$ \\
\hline 11 & 22 & $\mathrm{~F}$ & TSS & 63 & - & Cure & $1,6,12$ \\
\hline 12 & 23 & $\mathrm{~F}$ & TSS & 53 & - & Cure & $1,6,12$ \\
\hline 13 & 27 & $\mathrm{~F}$ & TSS & 137 & - & Cure & $1,6,12,18$ \\
\hline 14 & 31 & $\mathrm{~F}$ & TSS & 34 & - & Cure & $1,6,12$ \\
\hline 15 & 47 & $\mathrm{~F}$ & TSS & 545 & - & Normalization & 1,6 \\
\hline 16 & 17 & $\mathrm{~F}$ & TSS & 201 & - & Normalization & 1,6 \\
\hline 17 & 42 & $\mathrm{~F}$ & TSS & 605 & - & Relapse & $1,12 \S$ \\
\hline 18 & 46 & $\mathrm{~F}$ & TSS & 622 & - & Normalization & $1,6,18$ \\
\hline 19 & 29 & $\mathrm{~F}$ & TSS & 408 & - & Relapse & $1,6,12,18,24$ \\
\hline 20 & 26 & $\mathrm{~F}$ & TSS & 1109 & $\gamma \mathrm{U}+\mathrm{KC}$ & Normalization & 1 \\
\hline 21 & 43 & $\mathrm{~F}$ & TSS & 606 & $\gamma U+K C$ & Normalization & 1 \\
\hline 22 & 23 & $\mathrm{~F}$ & TSS & 814 & $\mathrm{KC}$ & Normalization & 1 \\
\hline 23 & 37 & $\mathrm{~F}$ & TSS + TSS & 740 & ADRX & Hypoadrenalism $\ddagger$ & 1 \\
\hline 24 & 35 & $\mathrm{~F}$ & TSS & 715 & - & Failure & $1 \S$ \\
\hline 25 & 34 & $\mathrm{~F}$ & TSS & 109 & - & Cure & 84 \\
\hline 26 & 41 & $\mathrm{~F}$ & TSS & 104 & - & Cure & 231 \\
\hline 27 & 33 & $M$ & TSS & 66 & - & Cure & 48 \\
\hline 28 & 39 & $\mathrm{~F}$ & TSS & 27 & - & Cure & 60 \\
\hline 29 & 25 & $\mathrm{~F}$ & TSS & $<10$ & - & Cure & 36 \\
\hline 30 & 28 & $\mathrm{~F}$ & TSS + TSS & $<10$ & - & Cure & 24 \\
\hline 31 & 45 & $\mathrm{~F}$ & TSS + TSS & 726 & RT & Cure & $24,36,48$ \\
\hline 32 & 52 & $\mathrm{~F}$ & TSS & 455 & $\mathrm{RT}$ & Normalization & $60,72,48$ \\
\hline 33 & 38 & $\mathrm{~F}$ & TSS & 504 & $\mathrm{RT}$ & Normalization & $48,72,84$ \\
\hline 34 & 51 & $\mathrm{~F}$ & TSS & 270 & $\gamma \mathrm{U}$ & Normalization & $12,24,36$ \\
\hline
\end{tabular}

TSS, transsphenoidal surgery; $\gamma \mathrm{U}$, gamma unit; KC, ketoconazole; ADRX, bilateral adrenalectomy; RT, radiotherapy. † Serum cortisol normal range $=140-700 \mathrm{nmol} / \mathrm{l}$.

$\ddagger$ After bilateral adrenalectomy; § lost to follow-up.

practice, as a certain degree of overlap occurs between hormonal responses in Cushing's disease and in normal individuals after administration of CRH and LVP.

The consistent lack of hormonal responses to desmopressin recorded in normal individuals might indicate the possible usefulness of this challenge in the post-surgical follow-up of Cushing's disease, for the recognition of true recurrences. In this respect, normal postoperative cortisol concentrations (9), hyperresponsiveness to $\mathrm{CRH}$ or metyrapone tests soon after surgery (10-12), or occasional paradoxical ACTH responses to the administration of thyrotrophin-releasing hormone (TRH)/gonadotrophin-releasing hormone (GnRH) (13, 14) have been associated with greater rates of relapse. Because, at present, no single test is considered to be of total value, the aim of the present study was to compare the ACTH/cortisol responses to desmopressin and $\mathrm{CRH}$ in patients with Cushing's disease either before or after pituitary adenomectomy during long-term follow-up.

\section{Patients and methods}

\section{Patients}

Thirty-four patients (32 women and 2 men, aged 1370 years) were studied (Table 1). Twenty-four patients with active Cushing's disease were evaluated both before and after transsphenoidal pituitary surgery (TSS), and two of them also underwent stereotactic radiosurgery (Gamma Unit); these patients were followed up for 1-36 months.

Ten patients were studied only after a long-term period (1-19 years, median 4 years) after TSS (patients Nos 25-30), TSS plus external pituitary irradiation (total dose of 48-54 Gy, patients Nos 31-33) and TSS plus radiosurgery (patient No. 34). Four patients (Nos 2, 23, 30 and 31) were operated on twice.

The diagnosis of Cushing's disease was made on the basis of clinical features and standard hormonal criteria: high urinary free cortisol (UFC) excretion, 
normal or high plasma ACTH and serum cortisol concentrations, absent suppression after low-dose dexamethasone tests (1 mg orally overnight and/or $2 \mathrm{mg} /$ day orally for $48 \mathrm{~h}$ ), but adequate suppression after high-dose dexamethasone tests $(8 \mathrm{mg}$ orally overnight and/or $8 \mathrm{mg} /$ day orally for $48 \mathrm{~h}$ ). Nuclear magnetic resonance imaging (MRI) and/or high resolution computed tomography of the sellar region showed a pituitary microadenoma in all but three patients (Nos 6, 14 and 26); two patients (Nos 20 and 32) had a macroadenoma. The diagnosis of Cushing's disease was confirmed in all patients after pituitary adenomectomy, as the histological examination showed the existence of adenomatous tissue, with positive staining for ACTH at immunohistochemical analysis.

Ten normal individuals (four women and six men, aged 23-31 years), recruited from medical staff, served as controls for the desmopressin test.

\section{Testing procedures}

All patients gave informed consent and underwent desmopressin and $\mathrm{CRH}$ tests in randomized order, starting at $0800 \mathrm{~h}$ after an overnight fast.

Desmopressin (Minirin/DDAVP, Ferring-S, Milan, Italy) was injected at a dose of $10 \mu \mathrm{g}$ i.v. as a bolus at time 0 min and blood samples for plasma ACTH and serum cortisol determinations were taken at $-30,0,15,30$, 45, 60, 90 and $120 \mathrm{~min}$.

Ovine CRH (Clinalfa, Läufelfingen, Switzerland) was administered at the dose of $1 \mu \mathrm{g} / \mathrm{kg}$ i.v. as a bolus at time $0 \mathrm{~min}$, with blood samples taken at $-30,0,20,30,60$, 90 and $120 \mathrm{~min}$.

In 24 patients, desmopressin and $\mathrm{CRH}$ tests were performed either before or after pituitary surgery. Fourteen (Nos 1-14) of them were judged as 'cured' on the basis of hormonal and clinical criteria. Serum cortisol concentrations were less than $140 \mathrm{nmol} / \mathrm{l} \mathrm{2-7}$ days after surgery; 30 days after TSS, UFC values were less than $35 \mathrm{nmol} /$ day and a normal cortisol suppression was present after $1 \mathrm{mg}$ dexamethasone (i.e. cortisol concentrations less than $140 \mathrm{nmol} / \mathrm{l}$ ). All patients needed corticosteroid replacement therapy (cortisone acetate $25-37.5 \mathrm{mg}$ /day). The dose was tapered and treatment stopped at least $24 \mathrm{~h}$ before the patients were investigated during the post-surgical follow-up (at 1, 6, 12, 18, 24 and 36 months). The replacement therapy was completely withdrawn on the basis of clinical criteria and when baseline cortisol/ACTH concentrations normalized and hypothalamic-pituitary-adrenal function fully recovered.

Five patients (Nos 15-19) only achieved normal cortisol concentrations (ranging between 140 and $700 \mathrm{nmol} / \mathrm{l}$ ) 2-7 days after adenomectomy. At the first month after TSS, UFC values were within the normal range $(35-275 \mathrm{nmol} /$ day) and serum cortisol was suppressed by $1 \mathrm{mg}$ dexamethasone. In these patients, desmopressin and $\mathrm{CRH}$ challenges were repeated at 1,6 , 12,18 and 24 months.

Five patients (Nos 20-24) who were operated on unsuccessfully underwent desmopressin and CRH tests only at 1 month after surgery.

Six of the remaining 10 patients (Nos 25-30) were cured and were investigated in conditions of persistent eucortisolism at 27-231 months after TSS; the other four patients not cured by surgery improved after pituitary irradiation and underwent both tests on repeated occasions (range 12-84 months).

\section{Hormone measurements}

Plasma ACTH $(1 \mathrm{pmol} / \mathrm{l}=4.5 \mathrm{pg} / \mathrm{ml})$ and serum cortisol $(1 \mathrm{nmol} / \mathrm{l}=0.0362 \mu \mathrm{g} / \mathrm{dl})$ concentrations were measured on unextracted samples by IRMA (Nichols Institute, San Juan Capistrano, CA, USA) and RIA (Diagnostic Products, Los Angeles, CA, USA) methods, respectively. The intra- and interassay coefficients of variation were $3.1-7.3 \%$ and $4.6-5.4 \%$, respectively. The lower limits of sensitivity were $0.44 \mathrm{pmol} / \mathrm{l}$ for plasma ACTH and $11 \mathrm{nmol} / \mathrm{l}$ for serum cortisol.

\section{Statistical analysis}

As previously defined (8), in each patient increases in ACTH and cortisol greater than $50 \%$ and $20 \%$ from baseline values, respectively (mean value of samples taken at -30 and $0 \mathrm{~min}$ ) were considered as positive responses to both tests. When net increments $(\Delta)$ in ACTH and cortisol were respectively less than $5 \mathrm{pmol} / \mathrm{l}$ and $200 \mathrm{nmol} / \mathrm{l}$, the hormonal response was considered insufficient, irrespective of the percentage increase.

Statistical analysis was performed by Student's $t$-test and by ANOVA test followed by Scheffé F-test.

\section{Results}

\section{Normal individuals}

Desmopressin administration did not elicit significant ACTH or cortisol responses in any normal individuals (ACTH from a baseline of $5.1 \pm 1.2 \mathrm{pmol} / \mathrm{l}$ to a peak of $5.5 \pm 0.9 \mathrm{pmol} / \mathrm{l}$; cortisol from $404 \pm 33 \mathrm{nmol} / \mathrm{l}$ to $420 \pm 48 \mathrm{nmol} / \mathrm{l}$; Fig. 1); the net increments ranged from -2 to $3.3 \mathrm{pmol} / \mathrm{l}$ for ACTH and from -48 to $150 \mathrm{nmol} / \mathrm{l}$ for cortisol.

\section{Patients with Cushing's disease: before surgery}

In 24 patients (Nos 1-24) with active Cushing's disease, a significant ACTH/cortisol response $(P<0.001)$ was induced by either desmopressin (ACTH from a baseline of $15.3 \pm 2.7 \mathrm{pmol} / \mathrm{l}$ to a peak of $40.9 \pm 7.3 \mathrm{pmol} / \mathrm{l}$; cortisol from $673 \pm 59 \mathrm{nmol} / \mathrm{l}$ to $1171 \pm 90 \mathrm{nmol} / \mathrm{l}$; Fig. 1) or $\mathrm{CRH}$ (ACTH from a basal of $14.2 \pm 2.5 \mathrm{pmol} / \mathrm{l}$ to a peak of $47.2 \pm 7.7 \mathrm{pmol} / \mathrm{l}$; cortisol from $672 \pm 50 \mathrm{nmol} / \mathrm{l}$ to 

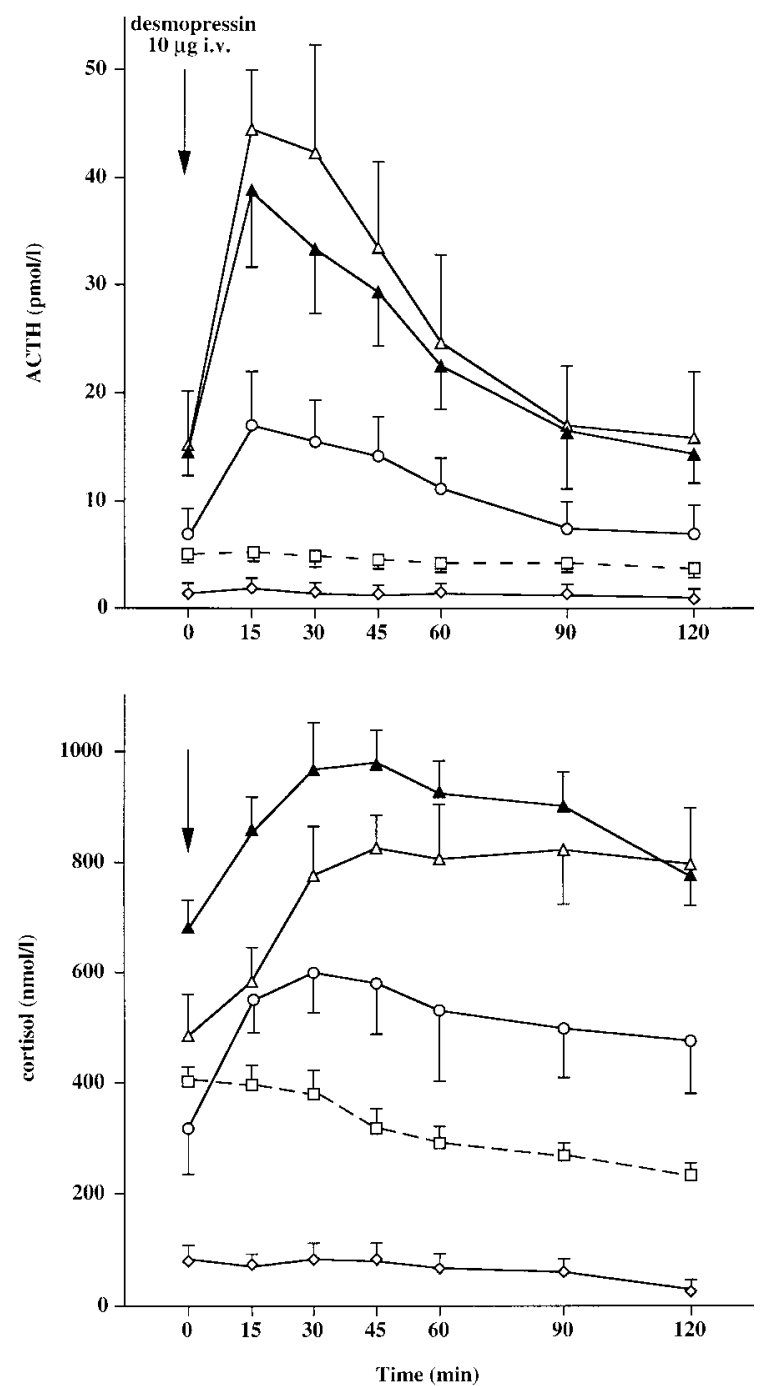

Figure 1 Changes in plasma ACTH and serum cortisol concentrations (means \pm S.E.) after $10 \mu \mathrm{g}$ i.v. desmopressin in 24 patients with active Cushing's disease (Nos 1-24, $\mathbf{\Lambda}$ ), in 12 'cured' patients 1 month after surgery (Nos 3-14, $\diamond$ ), in five unsuccessfully operated (Nos 20-24, $\triangle$ ), in five 'normalized' patients (Nos 15-19, O) and in 10 normal subjects ( $\square$, dotted lines). Positive responses were observed in patients with active Cushing's disease, in unsuccessfully operated and in 'normalized' patients.

$1192 \pm 80 \mathrm{nmol} / \mathrm{l})$. In all patients a positive cortisol response to desmopressin was found, but four patients (Nos 1, 7, 13 and 16) did not show a significant increase in ACTH after desmopressin. An absent ACTH and cortisol response after $\mathrm{CRH}$ administration was observed only in one woman (patient No. 6).

\section{Patients with Cushing's disease: follow-up after surgery alone or surgery plus radiotherapy}

The 14 'cured' patients (Nos 1-14) were followed up for 1-36 months after pituitary adenomectomy. One

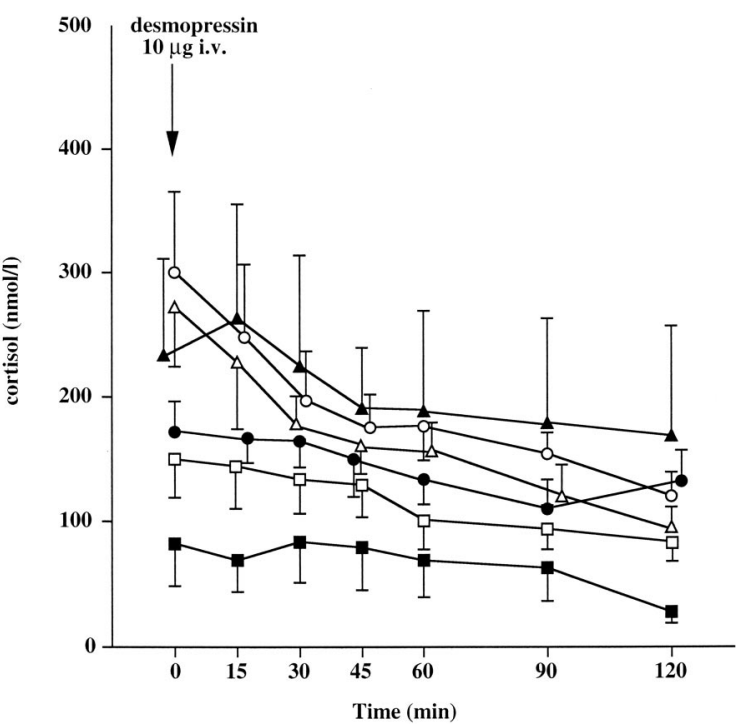

Figure 2 Absence of increase in serum cortisol (means \pm S.E.) after $10 \mu \mathrm{g}$ i.v. desmopressin in 'cured' patients at 1 month after surgery ( $n=12, \square), 6$ months $(n=11, \square), 12$ months $(n=13, \bullet), 18$ months $(n=6, \bigcirc), 24$ months $(n=8, \mathbf{\Lambda})$, and 36 months after surgery $(n=3$, $\triangle)$.

month after surgery, neither ACTH nor cortisol responses were observed after desmopressin (Fig. 1); no different hormonal responsiveness was found between the four patients with low-normal cortisol concentrations (Nos 6, 8, 9 and 13) and the remaining 10 patients (data not shown). During the follow-up period, in spite of a progressive increase in baseline cortisol concentrations from the 1 st to the 36 th month, desmopressin administration never induced a positive increase in cortisol in any patient (Fig. 2). In contrast, a progressive recovery of ACTH and cortisol responses after $\mathrm{CRH}$ was observed at different intervals of time in all patients but one (No. 8). Figure 3 shows the pattern of cortisol responses to desmopressin and CRH during follow-up. One month after surgery, the CRH test induced a positive increase in ACTH in three of 12 patients (Nos 5, 11 and 14), but no cortisol responses were recorded. At the 6th month, normal ACTH and cortisol responses to $\mathrm{CRH}$ were observed in four of 11 patients (Nos 6, 7, 12 and 14). Twelve months after surgery, nine of 13 patients (Nos 1, 2, 6, 7, 9, 10, 11, 12 and 14) showed an increase in ACTH after CRH and seven (Nos 2, 6, 7, 9, 12, 13 and 14) showed a normal cortisol increment. At the 18th month, positive ACTH and cortisol responses after $\mathrm{CRH}$ were observed in four of six cases (Nos 6, 7, 10 and 13). Two years after adenomectomy, five of the eight investigated patients (Nos 1, 4, 6, 7 and 10) showed a normal increase in ACTH/cortisol after CRH, and two (Nos 3 and 9) exhibited only a cortisol response. At the 36th month, only three patients were evaluated (Nos 2, 4 and 6), and they showed a positive responsiveness to CRH. 

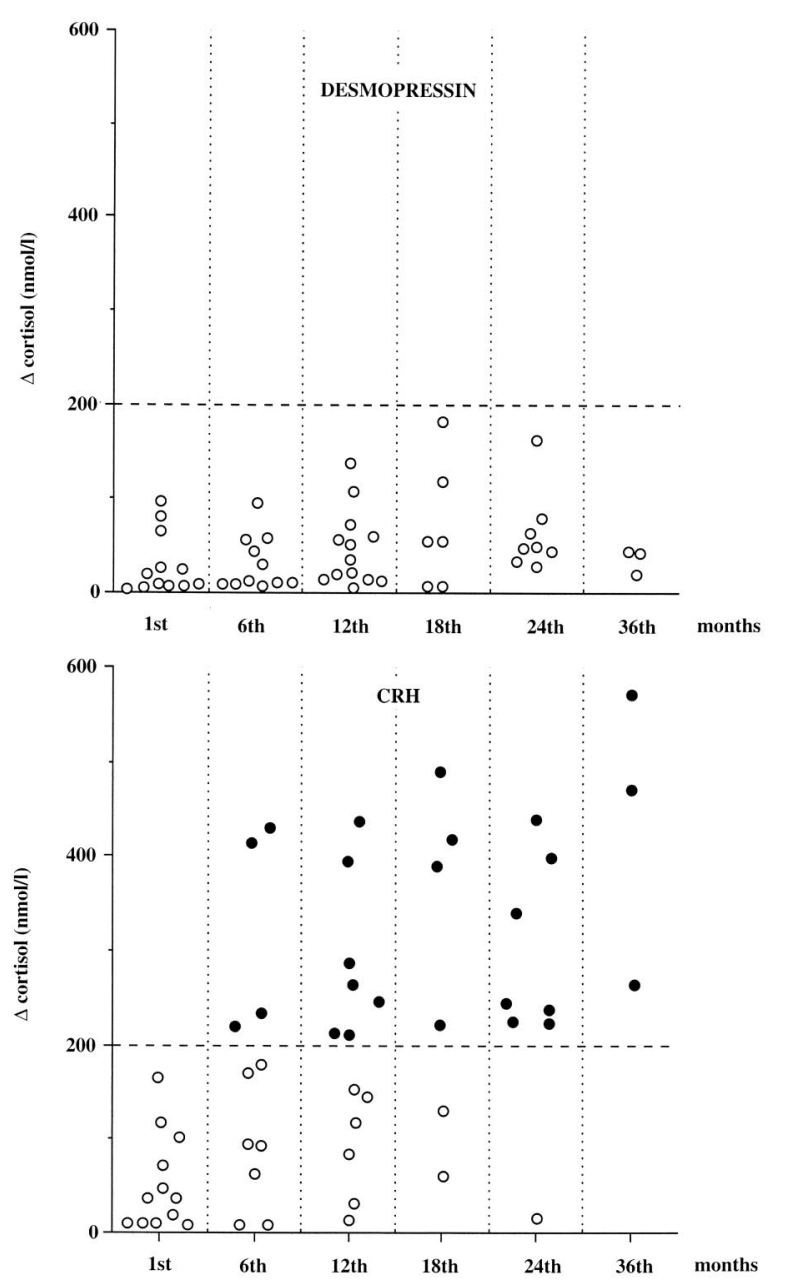

Figure 3 Net increments $(\Delta)$ in serum cortisol after desmopressin and $\mathrm{CRH}$ in 14 cured patients $(\bigcirc$, non-responders; $\bullet$, responders) with Cushing's disease, at 1, 6, 12, 18, 24 and 36 months after pituitary adenomectomy. A persistent absent response to desmopressin is shown, but a progressive recovery of responsiveness to $\mathrm{CRH}$ is observed. The horizontal dotted lines indicate the lower limits of positive responses.

Five patients (Nos 15-19) who only achieved normal cortisol concentrations soon after surgery, were followed up (Fig. 4). One month after operation, the ACTH and cortisol response curves after desmopressin were significantly different from those in normal individuals $(P<0.05)$ and did not differ from those of patients who were not cured (Fig. 1). Notably, at the 1st month three patients (Nos 15, 17 and 18) showed positive ACTH and cortisol responses to desmopressin, whereas in one patient (No. 16) desmopressin induced only an increase in cortisol, as in her preoperative evaluation; these four patients were CRH responders, also. During the followup, this pattern of responsiveness was maintained at the 6th (patients Nos 15, 16 and 18), 12th (patient No. 17) and 18th months (patient No. 18). It should be noted that, in patient No. 17, UFC excretion increased after the 6th month, whereas a normal cortisol inhibition was maintained; at the 12 month a clinical relapse and a positive visualization of adenoma appeared at MRI. In patient No. 19, a positive increase in cortisol after desmopressin was present from 1-24 months, whereas serum cortisol responded to $\mathrm{CRH}$ and was not suppressed by dexamethasone only after the 18th month. A clinical recurrence with high UFC values and positive MRI (which had been negative at the 12th month) appeared at the 24th month. Five patients (Nos 20-24) underwent unsuccessful surgery: their hormonal responsiveness to either $\mathrm{CRH}$ or desmopressin (Fig. 1) was superimposable before and after operation.

Ten patients (Nos 25-34) were studied only after long-term follow-up. Six of them were cured (Nos 2530) and a normal responsiveness to $\mathrm{CRH}$ was present, whereas no changes in ACTH and cortisol concentrations were induced by desmopressin. The other four patients (Nos 31-34) had been operated on unsuccessfully and then underwent pituitary irradiation. One of them (No. 31) showed a persistent hormonal response to desmopressin 24 months after irradiation $(\Delta$ ACTH $7.9 \mathrm{pmol} / \mathrm{l}$; $\Delta$ cortisol $452 \mathrm{nmol} / \mathrm{l}$ ); subsequently, the response to desmopressin was reduced, a hypocortisolism occurred and cortisone substitutive therapy was started. In patients Nos 32 and 33, desmopressin persistently increased ACTH concentrations (No. 32: $\Delta$ ACTH 5.7-14.1 pmol/l; No. 33: $\Delta$ ACTH 9.9$18.5 \mathrm{pmol} / \mathrm{l})$, whereas it induced either insufficient or positive increases in cortisol (No. 32: $\Delta$ cortisol 114$239 \mathrm{nmol} / \mathrm{l}$; No. 33: $\Delta$ cortisol $34-264 \mathrm{nmol} / \mathrm{l})$; the same pattern of equivocal responsiveness was also recorded after $\mathrm{CRH}$ testing. Patient No. 34 did not respond to desmopressin 12 months after radiosurgery, but positive increments reappeared at 24 and 36 months of follow-up (24th month: $\Delta$ ACTH $7.4 \mathrm{pmol} /$ l, $\Delta$ cortisol $185 \mathrm{nmol} / \mathrm{l}$; 36th month: $\Delta$ ACTH $12.5 \mathrm{pmol} / \mathrm{l}, \Delta$ cortisol $889 \mathrm{nmol} / \mathrm{l})$; throughout this period an ACTH/cortisol response to $\mathrm{CRH}$ test had been always present.

\section{Discussion}

Long-standing experience with the CRH test has shown that this peptide is able to induce a significant increase in plasma ACTH and serum cortisol in the great majority of patients with Cushing's disease, whereas this pattern of response rarely occurs in other forms of hypercortisolism (1). Moreover, the ACTH-releasing activity of vasopressin and its analogues, mediated by the V3 (V1b) receptors recently cloned in the pituitary $(3,4)$, has led to the use of desmopressin in trying to discriminate better between pituitary or ectopic sources of ACTH hypersecretion in ACTH-dependent Cushing's syndrome. With a greater relative affinity for the renal V2 receptors and less action on V1 pressor receptor family, desmopressin has replaced arginine- and lysinevasopressin in clinical testing for Cushing's syndrome, 


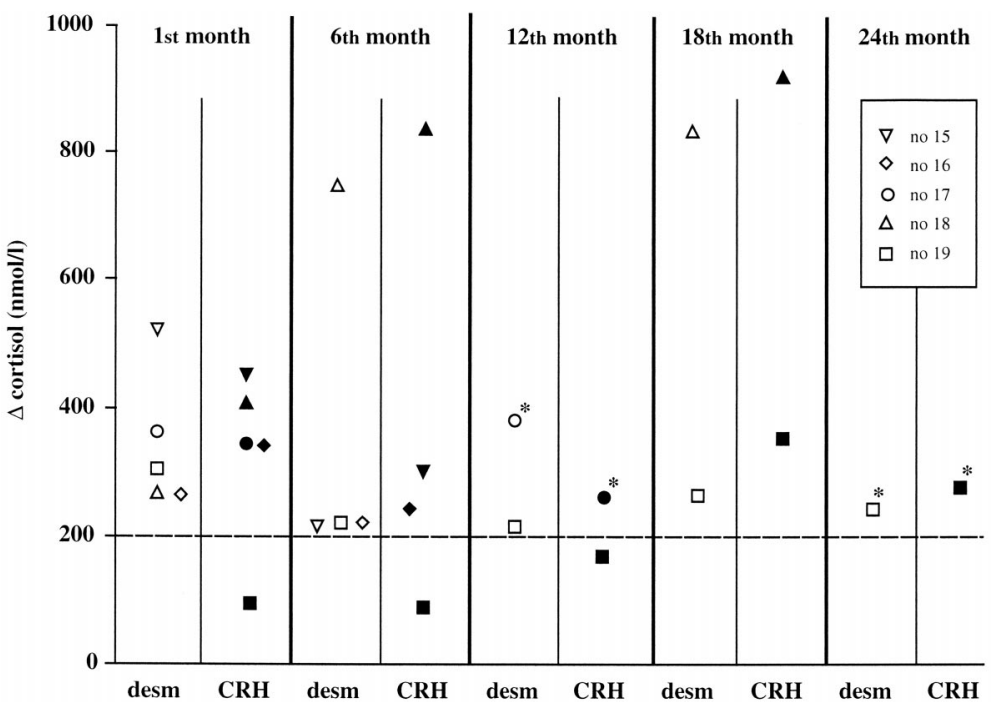

Figure 4 Net increments $(\Delta)$ in serum cortisol after desmopressin (desm, open symbols) and $\mathrm{CRH}$ (closed symbols) in the five patients who had normal postoperative cortisol concentrations, at $1,6,12,18$ and 24 months after surgery. The horizontal dotted lines indicate the lower limits of positive responses. The asterisks indicate the appearance of relapse in patients Nos 17 and 19. thanks to the virtual absence of side-effects. Presumably because of overexpression of $\mathrm{V} 3$ receptors and/or expression of $\mathrm{V} 2$ receptors in corticotrophinomas (5), experience accumulated up to now has documented that, similarly to administration of $\mathrm{CRH}$, that of desmopressin causes significant increases in ACTH and cortisol in most patients with Cushing's disease $(6-8,15)$. However, evidence that the same pattern of response occurs in some patients with ectopic Cushing's syndrome has been presented in either published $(7,16)$ or preliminary reports (17-19), and in this context the expression of both V3 and V2 vasopressin receptor subtypes in bronchial carcinoids has been demonstrated $(5,16,20)$. At present, it appears that the value of the desmopressin test in the differential diagnosis of ACTHdependent Cushing's syndrome is questionable, although in individual patients it may represent an adjunctive tool, particularly in cases of doubtful hormonal results after $\mathrm{CRH}$ or other dynamic tests. Indeed, improved discrimination between Cushing's disease and ectopic Cushing's syndrome was achieved with a combined test with both desmopressin and CRH injection (7).

The results here reported extend, therefore, those in our previous paper (8), particularly with respect to the possible clinical value of the desmopressin test during the post-surgical follow-up of Cushing's disease.

Notwithstanding the aforementioned remarks concerning the 'doubtful' diagnostic usefulness of desmopressin test, our data do confirm that, given a significant increase in ACTH and/or cortisol after desmopressin in an individual patient with Cushing's disease, the same pattern of response is reproducible in cases of unsuccessful surgery, as occurred in five of our patients studied before and after operation. In line with this, and even in the absence of data concerning the desmopressin test before pituitary adenomectomy, the finding of persistent ACTH responses to this peptide in another three unsuccessfully operated and subsequently irradiated patients (Nos 32-34) may suggest the persistence of adenomatous corticotrophs after long-term follow-up.

In another two patients (Nos 17 and 19) who only achieved normal cortisol concentrations soon after surgery, a clinical and biochemical recurrence of Cushing's disease occurred after 12 and 24 months, respectively. Interestingly, whereas the hormonal response to desmopressin in both patients had reappeared at the 1st month and never disappeared during follow-up, in one of them the initially absent cortisol response to $\mathrm{CRH}$ - and the lack of suppressibility by dexamethasone - reappeared only after 18 months. Although a clinical recurrence of the disease occurred only months later, it is difficult to speak in terms of 'true recurrence' in these patients, as the finding of normal cortisol concentrations in the immediate post-surgical period has been related to an incomplete removal of adenomatous corticotrophs. Therefore, the persistent responsiveness to desmopressin may be a constant feature of unsuccessful surgery, even in the absence of clinical and biochemical evidence of active Cushing's disease. It is suggested that these patients need a more strict follow-up, with a monthly hormonal evaluation; if the hypercortisolism is confirmed and clinical features also appear, further therapeutic intervention is required.

Compared with our previous results (8), the data obtained in a larger group of normal individuals confirm the consistent lack of significant ACTH/cortisol responses to this peptide in this population $(6,15,21)-$ a feature that might be a consequence of an insufficient expression of $\mathrm{V} 3$ receptors in normal corticotrophs. This consideration prompted us to evaluate whether the desmopressin challenge might be of value in the postoperative follow-up of patients with Cushing's disease after successful surgery. 
Although it is generally accepted that the finding of low serum and urinary cortisol concentrations soon after adenomectomy provides the best predictive index of 'cure' of the disease $(9,10,14)$, the overall data concerning the long-term follow-up of large series of patients indicate that a risk of 'true recurrences' is always present. It has been suggested that the finding of ACTH hyperresponsiveness to an early postoperative $\mathrm{CRH}$ test might be a valuable index with which to identify those patients with a greater risk of recurrence $(10,22)$ and this criterion was judged to be more specific than the demonstration of subnormal serum and urinary cortisol values soon after surgery (11). Moreover, the occurrence of preoperative paradoxical responses to $\mathrm{TRH} / \mathrm{GnRH}$ has also been related to a greater percentage of relapse, although in very few patients $(13,14)$, and it has been recently shown that the metyrapone test is useful for the early detection of patients at risk of a recurrence (12). However, no single test exists that provides an accurate prediction of relapse of hypercortisolism, and problems can arise in the correct and early recognition of this situation, particularly during the recovery of 'normal' hypothalamicpituitary-adrenal function. In this regard, the CRH test is no exception; our results in 14 patients exhibiting hypocortisolism immediately after surgery reflected the common experience with this peptide. In fact, a progressive recovery of positive ACTH/cortisol responses occurred in 13 of them, particularly after the 6th month, concomitant with the withdrawal of replacement therapy and, notably, with a substantial overlap compared with responses obtained before surgery. Different conclusions can be drawn from the results of the desmopressin test in the same patients, as the positive responsiveness recorded during active disease disappeared completely after surgery, and remained unchanged throughout the entire period of follow-up. In addition, an absent hormonal response was observed in another six patients studied only after operation and who remain persistently cured after 2-19 years of follow-up; it is of interest that a lack of responsiveness was found 4-19 years after surgery also in three patients (Nos 25-27) with low-normal cortisol concentrations in the early postoperative period. These findings confirm the complementary role of the desmopressin challenge with respect to the CRH test in the follow-up of Cushing's disease, as the disappearance of hormonal responses to this peptide seems to be a constant feature of patients who had been cured by either surgical or radiation therapy. In this context, desmopressin might provide improved discrimination of cure, as it seems helpful in better recognizing whether the recovery of ACTH/cortisol responses to CRH represents a recovery of normal pituitary-adrenal function or, instead, a reactivation of the disease. However, the present data need to be confirmed with longer periods of follow-up and wider experience with this test.
In conclusion, apart from diagnostic purposes, a positive ACTH/cortisol response to desmopressin in Cushing's patients retains value as an individual marker of the disease. Moreover, during the follow-up, the maintenance or disappearance of the hormonal response may be related to the persistence or complete removal of adenomatous corticotrophs, respectively. As release of ACTH and cortisol after desmopressin occurs in most patients with ACTH-secreting pituitary adenomas, it is mandatory to perform the test as part of the preoperative investigation, in order to interpret its results during the follow-up. Further studies are needed to determine whether this test may become a useful adjunct in detecting the risk of a 'true' recurrence of disease in patients with postoperative hypoadrenalism and who do not respond to the peptide after 'cure'.

\section{Acknowledgements}

This work was partially supported by grants from Ospedale Maggiore IRCCS, Milano and from MURST, Roma (No. 9706151106).

We thank Miss Antonia Maffini for her skilled technical assistance.

\section{References}

1 Orth DN. Corticotropin-releasing hormone in humans. Endocrine Reviews $199213164-191$.

2 Tabarin A, San Galli F, Dezou S, Leprat F, Corcuff JB, Latapie JL et al. The corticotropin-releasing factor test in the differential diagnosis of Cushing's syndrome: a comparison with the lysinevasopressin test. Acta Endocrinologica 1990123 331-338.

3 Sugimoto T, Saito M, Machizuki S, Watanabe Y, Hashimoto S \& Kawashima H. Molecular cloning and functional expression of a cDNA encoding the human V1b vasopressin receptor. Journal of Biological Chemistry $199426927088-27092$.

4 de Keyzer Y, Auzan C, Lenne F, Beldjord C, Thibonnier M, Bertagna $\mathrm{X}$ et al. Cloning and characterization of the human V3 pituitary vasopressin receptor. FEBS Letters 1994356 215-220.

5 Dahia PLM, Ahmed-Shuaib A, Jacobs RA, Chew SL, Honegger J, Fahlbusch R et al. Vasopressin receptor expression and mutation analysis in corticotropin-secreting tumors. Journal of Clinical Endocrinology and Metabolism 199681 1768-1771.

6 Malerbi DA, Mendonça BB, Liberman B, Toledo SPA, Corradini MCM, Cunha-Neto MB et al. The desmopressin stimulation test in the differential diagnosis of Cushing's syndrome. Clinical Endocrinology 199338 463-472.

7 Newell-Price J. Perry L, Medbak S, Monson J. Savage M, Besser M et al. A combined test using desmopressin and corticotropinreleasing hormone in the differential diagnosis of Cushing's syndrome. Journal of Clinical Endocrinology and Metabolism 1997 82 176-181.

8 Colombo P, Passini E, Re T, Faglia G \& Ambrosi B. Effects of desmopressin on ACTH and cortisol secretion in states of ACTH excess. Clinical Endocrinology 199746 661-668.

9 Trainer PJ, Lawrie HS, Verhelst J, Howlett TA, Lowe DG, Grossman $\mathrm{AB}$ et al. Transsphenoidal resection in Cushing's disease: undetectable serum cortisol as the definition of successful treatment. Clinical Endocrinology 199338 73-78.

10 Schrell U, Fahlbusch R, Buchfelder M, Riedl S, Stalla GK \& Müller OA. Corticotropin-releasing hormone stimulation test before and after transsphenoidal selective microadenomectomy in 30 patients with Cushing's disease. Journal of Clinical Endocrinology and Metabolism 198764 1150-1159. 
11 Vignati F, Berselli ME \& Loli P. Early postoperative evaluation in patients with Cushing's disease; usefulness of ovine corticotropinreleasing hormone in the prediction of recurrence of disease. European Journal of Endocrinology 1994130 235-241.

12 van Aken MO, de Herder WW, van der Lely A, de Jong FH \& Lamberts SWJ. Postoperative metyrapone test in the early assessment of outcome of pituitary surgery for Cushing's disease. Clinical Endocrinology 199747 145-149.

13 Pieters GFFM, Hermus ARMM, Meijer E, Smals AGH \& Kloppenborg PWC. Predictive factors for initial cure and relapse rate after pituitary surgery for Cushing's disease. Journal of Clinical Endocrinology and Metabolism 198969 1122-1126.

14 Bochicchio D, Losa M, Buchfelder M \& the European Cushing's Disease Survey Study Group. Factors influencing the immediate and late outcome of Cushing's disease treated by transsphenoidal surgery: a retrospective study by the European Cushing's Disease Survey Group. Journal of Clinical Endocrinology and Metabolism $1995803114-3120$.

15 Sakai Y, Horiba N, Tozawa F, Kuwayama A. Demura H \& Suda T. Desmopressin stimulation test for diagnosis of ACTH-dependent Cushing's syndrome. Endocrine Journal 199744 687-695.

16 Arlt W, Dahia PLM, Callies F, Nordmeyer JP, Allolio B, Grossman $\mathrm{AB}$ et al. Ectopic production by a bronchial carcinoid tumour responsive to desmopressin in vivo and in vitro. Clinical Endocrinology $199747623-627$.

17 Raff H, Kehoe ME \& Findling JW. DDAVP increases inferior petrosal sinus ACTH concentration in patients with pituitary and ectopic ACTH-dependent Cushing's syndrome. In Program and Abstract of the 77th Meeting of the Endocrine Society, Washington, DC, 14-17 June 1995, Abstract OR 39-6. Bethesda, MD, USA Endocrine Society Press.
18 Heppner C, Petzke U, Allolio B, Reincke M, Klingmuller D, MullerWieland D et al. Desmopressin stimulation test in the differential diagnosis of ACTH-dependent Cushing's syndrome. In Program and Abstract of the 10th International Congress of Endocrinology, San Francisco, CA, 12-15 June 1996, Abstract OR 5-6. Bethesda, MD, USA: Endocrine Society Press.

19 Vignati F, Cassani M, Da Re N \& Loli P. Desmopressin stimulation test in the diagnosis of Cushing's syndrome and pseudo-Cushing states. In Program and Abstract of the 10th International Congress of Endocrinology, San Francisco, CA, 12-15 June 1996, Abstract P3-586. Bethesda, MD, USA: Endocrine Society Press.

20 de Keyzer Y, Lenne F, Auzan C, Jegou S, Rene P, Vaudry H et al. The pituitary V3 receptor and the corticotroph phenotype in ectopic ACTH syndrome. Journal of Clinical Investigation $1996971311-$ 1318.

21 Ceresini G, Freddi M, Paccotti P, Valenti G \& Merchenthaler I. Effects of ovine corticotropin-releasing hormone injection and desmopressin coadministration on galanin and adrenocorticotropin plasma levels in normal women. Journal of Clinical Endocrinology and Metabolism 199782 607-610 .

22 Avgerinos PC, Chrousos GP, Nieman LK, Oldfield EH, Loriaux DL \& Cutler GB. The corticotrophin-releasing hormone test in the postoperative evaluation of patients with Cushing's syndrome. Journal of Clinical Endocrinology and Metabolism 198765 906913.

Received 20 July 1999

Accepted 17 March 2000 